\title{
Peptides as toxins/defensins
}

\author{
Mario Sergio Palma
}

Received: 2 August 2010/ Accepted: 13 August 2010/Published online: 24 August 2010

(C) Springer-Verlag 2010

Peptides have important roles in many physiological processes, functioning as neurotransmitters, hormones, toxins, antibiotics, and defensins. Venom peptides target a wide variety of membrane protein receptors and may interact directly with the phospholipids of the plasma/organelle membranes or with cytosolic proteins to regulate their activities. Venomous animals use peptides in their predation strategies, defence against territorial intruders, and prevention against infections by pathogenic microorganisms (Palma 2006; Turillazzi et al. 2006). These peptides are directed against a wide range of pharmacological targets and can induce pain, inflammation, blood pressure changes, heart arrhythmia, and neurotoxicity, among other toxic actions (De Souza and Palma 2009).

Many of the peptides from animal venoms and toxic secretions seem to have evolved convergently with their cellular and molecular targets to optimize their effects, making them highly selective ligands for specific types of receptors. The wide array of molecular structures that induce physiological and pharmacological actions on the victims underscores the high degree of plasticity for these peptide toxins. For each group of venomous organisms, nature adopted a different strategy to create peptide toxins, based on the biology, life history, longevity, and foraging/ feeding behaviour, among other factors. The venoms of Hymenoptera insects became a rich source of short linear polycationic peptides with multifunctional activities to cause pain and generalized inflammation (Palma 2006). Scorpions and wandering spiders evolved their venoms to

M. S. Palma $(\bowtie)$

Centre of Study of Social Insects (CEIS)/Department of Biology, Institute of Biosciences of Rio Claro, São Paulo State University (UNESP), Rio Claro, SP 13506-900, Brazil

e-mail: mspalma@rc.unesp.br contain structurally compact peptides due to the presence of disulfide bonds; and, these peptides are characterized by their high affinity for ion channels and/or nervous receptors, causing activation or blockage of the ion flux through the cellular membranes (Escoubas 2006; Sollod et al. 2005). Snake venom has evolved to have linear peptides that act on the receptors localized on the endothelium surface. These peptides form their secondary structure upon interacting with the targeted receptors, and this generally produces a decrease in the blood pressure of the victims (Fry et al. 2003; Fry 2005). The skin secretions of many amphibian groups contain linear polycationic and/or polyanionic peptides that are structurally simple and have antimicrobial activities (Nicolas et al. 2003).

Many organisms produce short charged amphiphilic peptides that have antimicrobial activity at physiological concentrations. They are part of an ancient innate nonspecific immune system, and in many cases, their primary function is to kill the invading pathogens. These peptides are known as antimicrobial peptides (AMPs).

AMPs have been isolated from animal venoms, bacterial secretions, and hemolymphs from arthropods, plants, amphibians, birds, fish, and mammals, including humans (Sitaram et al. 2003). Bacterial AMPs contribute to the survival of individual bacterial cells by attacking the bacteria that compete for nutrients in the same medium (Klaenhammer 1988).

In higher organisms, AMPs may be constitutively expressed or induced by a series of infectious/inflammatory stimuli (Hancock 2001). Some AMPs are potent modulators of the innate immune system (Bowdish et al. 2005), promoting phagocytosis and/or prostaglandin release or acting as chemoattractants for different types of immune cells to the site of inflammation (Yang et al. 2002). The main role attributed to these peptides is their direct biocidal 
actions towards bacteria, fungi, and parasites. However, the importance of the host defence activity depends on the site specificity of action within each organism (Jenssen et al. 2006).

Mammalian AMPs generally are chemotactic for human monocytes and $\mathrm{T}$ cells but may have adjuvant and polarizing effects in dendritic cell development. These peptides appear to have had an active role in the transition to the adaptive immune response (Chertov et al. 1996). Although AMPs may act directly on microbial cells by damaging or destabilizing the cell membrane, they seem to be involved in the organization of the innate immune and inflammatory responses (Hancock and Diamond 2000). They are also known as host defence peptides or defensins.

Defensins are widely distributed in plants, insects, reptiles, birds, and mammals (Zasloff 2002). Mammalian defensins are generally classified into three structural groups: $\alpha-, \beta-$, and $\theta$-defensins. The $\alpha$-defensins and $\beta$-defensins differ from each other by their pattern of disulfide bonds and the number of cationic charges. The $\theta$-defensins are characterized by the splicing and cyclisation of two of the nine amino acids in $\alpha$-defensins (Ganz 2003). In addition to controlling bacterial growth and development, the $\beta$-defensins may act against fungi (Song et al. 2009).

The structure, molecular targets, and mechanisms of action of AMPs/defensins differ with the animal species. Depending on the amino acid sequence, the secondary structures of these peptides may adopt the following four distinct conformations: (1) $\alpha$-helix, (2) $\beta$-strand, (3) $\beta$-hairpin, and (4) extended conformation. Most AMPs are unstructured in aqueous solutions; however, due to their amphiphilic nature, they interact with biological membranes and adopt a relatively organized secondary structure. These peptides may utilise a variety of antimicrobial actions, such as membrane perturbation and cell permeabilisation, to interact with its cytoplasmic and organellar targets (Ganz 2003).

The amino acid sequence of classical AMPs determines their general organization into four large groups:

1. Anionic rich in aspartic acid and/or glutamic acid residues, such as reported in the maximin $\mathrm{H} 5$ peptide from amphibians (Lai et al. 2002).

2. Linear cationic $\alpha$-helical peptides rich in lysine, arginine and/or histidine residues but lacking cysteine residues, as observed in insect peptides, like mellitin and mastoparans (Palma 2006).

3. Cationic enriched with some specific amino acid residues (proline, arginine, phenylalanine, glycine and tryptophan), such as reported in the abaecins and apidaecins from honeybee hemolymph (Bulet and Stöcklin 2005).
4. Anionic and cationic peptides contain disulfide bondforming cysteine residues and are found in drosomycins from fruit fly hemolymph (Cohen et al. 2009), human defensins (Schneider et al. 2005), and tachyplesins from horseshoe crabs (Muta et al. 1990).

Antimicrobial peptides act through different mechanisms, such as killing bacteria by membrane disruption, interfering with the metabolism, and interacting with cytoplasmic targets. Most bacterial membranes have anionic surfaces, suggesting that the interaction between the AMPs and microorganisms are initially electrostatic in nature. Depending on the amino acid sequence, AMPs can present different biophysical features (i.e., amphiphilicity, charge, and size) to interact with biological membranes to penetrate into the cell through one of the classical mechanisms (barrel-stave, carpet, and toroidal pores) or novel ones. Upon entry into the cells, the peptides can bind to their cytoplasmic/organellar molecular targets, inhibit the synthesis of the cell wall, interfere in the organization of the cytoplasmic membrane, and inhibit the synthesis of DNA, RNA, and proteins (Hancock and Diamond 2000; Hancock 2001).

The current research on toxic peptides and defensins is continually reporting molecular structures that are similar to the classical peptides and novel molecular structures that have either well-known physiological/pharmacological mechanisms or unidentified functional roles. As we further investigate these natural peptides, we become more aware of their potency, selectivity, and multifunctionality. To provide a broad overview of the current progress in the area of toxic peptides and defensins, we gathered contributions from chemists, biochemists, biophysicists, toxinologists, zoologists, and microbiologists. This issue is intended to present snapshots of the peptides identified as toxins/ defensins and to explore the diversity of biological systems, novel structures, and the mechanisms of action. The reviews and original manuscripts in this issue focus on peptides from insects (De Souza et al. 2010; Leite et al. 2010), spiders (Kuhn-Nentwig et al. 2010; Rodríguez et al. 2010; Santos et al. 2010), amphibians (Calderon et al. 2010; Libério et al. 2010; Meneses et al. 2010), and humans (Corrales-Garcia et al. 2010) by using spectroscopic strategies for the detection, structural elucidation (Barbosa et al. 2010; De Souza et al. 2010; Leite et al. 2010), and characterization of the molecular interactions with biological membranes (De Souza et al. 2010; Zhou et al. 2010). Some of the contributions focus on the studies of the structure-activity relationship to achieve a better understanding of the mechanisms of the action (Zhou et al. 2010). A series of novel and classical biological assays is reported to screen peptides for antimicrobial (KuhnNentwig et al. 2010; Rodríguez et al. 2010; Santos et al. 
2010; Zhou et al. 2010), insecticidal (Kuhn-Nentwig et al. 2010), inflammatory, algesic (Brigatte et al. 2010), and anticancer/antiproliferative actions (Kuhn-Nentwig et al. 2010; Libério et al. 2010), opening the possibilities to exploit these peptides in drug discovery programs and biotechnological applications (Barbosa et al. 2010; Calderon et al. 2010; Vetter et al. 2010).

Acknowledgments Thanks to all of the authors for their personal dedication and their contributions, as well as to Professor Gert Lübec for the opportunity to publish this issue in Amino Acids.

\section{References}

Barbosa SC, Cilli EM, Dias LG, Stabeli RG, Ciancaglini P (2010) Labaditin, a cyclic peptide with rich biotechnological potential: preliminary toxicological studies and structural changes in water and lipid membrane environment. Amino Acids (this issue)

Bowdish DM, Davidson DJ, Hancock R EW (2005) A re-evaluation of the role of host defence peptides in mammalian immunity. Curr Protein Pept Sci 6:35-51

Brigatte P, Cury Y, De Souza BM, Baptista-Saidemberg NB, Saidemberg DM, Gutierrez VP, Palma MS (2010) Hyperalgesic and edematogenic effects of peptides isolated from the venoms of honeybee (Apis mellifera) and neotropical social wasps (Polybia paulista and Protonectarina sylveirae). Amino Acids (this issue)

Bulet P, Stöcklin R (2005) Insect antimicrobial peptides: structures, properties and gene regulation. Prot Pept Lett 12:3-11

Calderon LA, Silva AAE, Ciancaglini P, Stabeli RG (2010) Antimicrobial peptides from Phyllomedusa frogs: from biomolecular diversity to potential nanotechnologic medical applications. Amino Acids (this issue)

Chertov O, Michiel DF, Xu L, Wang JM, Tani K, Murphy WJ, Longo DL, Taub DD, Oppenheim JJ (1996) Identification of defensin-1, defensin-2, and CAP37/azurocidin as T-cell chemoattractant proteins released from interleukin-8 stimulated neutrophils. J Biol Chem 271:2935-2940

Cohen L, Moran Y, Sharon A, Segal D, Gordon D, Gordon D, Gurevitz M (2009) Drosomycin, an innate immunity peptide of Drosophila melanogaster, interacts with the fly voltage-gated sodium channel. J Biol Chem 284:23558-23563

Corrales-Garcia LL, Possani LD, Corzo G (2010) Expression systems of human $\beta$ defensins: vectors, purification and biological activities. Amino Acids (this issue)

De Souza BM, Palma MS (2009) Peptides from Hymenoptera venoms: chemistry, biochemistry and potential applications in health and biotechnology. In: De Lima ME, PImenta AMC, Martin-Euclaire MF, Zingali RB (eds) Animal toxins: the state of art. UFMG Press, Belo Horizonte, pp 345-369 (pp 750)

De Souza BM, dos Santos Cabrera MP, Ruggiero Neto J, Palma MS (2010) Investigating the effect of different positioning of lysine residues along the peptide chain of mastoparans for their secondary structures and biological activities. Amino Acids (this issue)

Escoubas P (2006) Molecular diversification in spider venoms: a web of combinatorial peptide libraries. Mol Divers 10:545-554

Fry BG (2005) From genome to "venome": molecular origin and evolution of the snake venom proteome inferred from phylogenetic analysis of toxin sequences and related body proteins. Genome Res 15:403-420
Fry BG, Wuster W, Kini RM, Brusic V, Khan A, Venkataraman AD, Rooney AP (2003) Molecular evolution and phylogeny of elapid snake venom three-finger toxins. J Mol Evol 5:110-129

Ganz T (2003) Antimicrobial peptides of innate immunity. Nat Rev Immunol 3:710-720

Hancock RE (2001) Cationic peptides: effectors in innate immunity and novel antimicrobials. Lancet Infect Dis 1:156-164

Hancock RE, Diamond G (2000) The role of cationic antimicrobial peptides in innate host defences. Trends Microbiol 8:402-410

Jenssen H, Hamill P, Hancock REW (2006) Peptide antimicrobial agents. Clin Microbiol Rev 19:491-511

Klaenhammer TR (1988) Bacteriocins of lactic acid bacteria. Biochimie 70:337-349

Kuhn-Nentwig L, Willems J, Seebeck T, Shalaby T, Kaiser M, Nentwig W (2010) Cupiennin 1a exhibits a remarkably broad, non-stereospecific cytolytic activity on bacteria, protozoan parasites, insects, and human cancer cells. Amino Acids (this issue)

Lai R, Liu H, Lee WH, Zhang Y (2002) An anionic antimicrobial peptide from toad Bombina maxima. Biochem Biophys Res Commun 295:796-799

Leite NB, da Costa LC, Alvares DS, dos Santos Cabrera MP, De Souza BM, Palma MS, Ruggiero Neto J (2010) The effect of acidic residues and amphipathicity on the lytic activities of mastoparan peptides studied by fluorescence and CD spectroscopy Amino Acids 39(1) (this issue)

Libério MS, Joanitti GA, Azevedo RB, Cilli EM, Zanotta LC, Nascimento AC, Sousa MV, Pires Júnior OP, Fontes W, Castro MS (2010) Anti-proliferative and cytotoxic activity of pentadactylin isolated from Leptodactylus labyrinthicus on melanoma cells. Amino Acids (this issue)

Meneses EP, Villa-Hernández O, Hernández-Orihuela L, CastroFranco R, Pando V, Aguilar MB, Batista VF (2010) Peptidomic analysis of the skin secretions of the frog Pachymedusa dacnicolor. Amino Acids (this issue)

Muta T, Fujimoto T, Nakajima H, Iwanaga S (1990) Tachyplesins Isolated from Hemocytes of Southeast Asian Horseshoe Crabs (Carcinoscorpius rotundicauda and Tachypleus gigas) Identification of a new tachyplesin, tachyplesin III, and a processing intermediate of its precursor. J Biochem 108:261-266

Nicolas P, Vanhoye D, Amiche M (2003) Molecular strategies in biological evolution of antimicrobial peptides. Peptides 24:1669-1680

Palma MS (2006) Insect venom peptides (chapter 56). In: Kastin A (ed) Handbook of biologically active peptides. Academic Press, San Diego, pp 409-417 (pp 1545)

Rodríguez A, Villegas E, Satake H, Possani LD, Corzo G (2010) Amino acid substitutions in an alpha-helical antimicrobial arachnid peptide affect its chemical properties and biological activity towards pathogenic bacteria but improves its therapeutic index. Amino Acids (this issue)

Santos DM, Verly RM, Piló-Veloso D, de Maria M, de Carvalho MAR, Cisalpino PS, Soares BM, Diniz CG, Farias LM, Moreira DFF, Frézard F, Bemquerer MP, Pimenta AMC, de Lima ME (2010) LyeTxI, a potent antimicrobial peptide from the venom of the spider Lycosa erythrognatha. Amino Acids 39:135-144

Schneider JJ, Unholzer A, Schaller M, Schäfer-Korting M, Korting HC (2005) Human defensins. J Mol Med 83:587-595

Sitaram N, Subbalakshmi C, Nagaraj R (2003) Indolicidin, a 13-residue basic antimicrobial peptide rich in tryptophan and proline, interacts with $\mathrm{Ca}(2+)$-calmodulin. Biochem Biophys Res Commun 309:879-884

Sollod BL, Wilson D, Zhaxybayeva O, Gogarten JP, Drinkwater R, King $G$ (2005) Were arachnids the first to use combinatorial peptide libraries? Peptides 26:131-139 
Song W, Shi Y, Xiao M, Lu H, Qu T, Li PWG, Tian Y (2009) In vitro bactericidal activity of recombinant human-defensin-3 against pathogenic bacterial strains in human tooth root canal. Int $\mathbf{J}$ Antimicrob Agents 33:237-243

Turillazzi S, Mastrobuoni G, Dani FR, Moneti G, Pieraccini G, la Marca G, Bartolucci G, Perito B, Lambardi D, Cavallini V, Dapporto L (2006) Dominulin A and B: two new antibacterial peptides identified on the cuticle and in the venom of the social paper wasp Polistes dominulus using MALDI-TOF, MALDI-TOF/TOF, and ESI-ion trap. J Am Soc Mass Spectrom 17:376-383

Vetter I, Davis JL, Rash LD, Anangi R, Mobli M, Alewood PF, Lewis RJ, King GF (2010) Venomics: a new paradigm for natural products-based drug discovery. Amino Acids (this issue)
Yang D, Biragyn A, Kwak LW, Oppenheim JJ (2002) Mammalian defensins in immunity: more than just microbicidal. Trends Immunol 23:291-296

Zasloff M (2002) Antimicrobial peptides of multicellular organisms. Nature 415:389-395

Zhou L, Liu SP, Chen LY, Li J, Ong LB, Guo L, Wohland T, Tang CC, Lakshminarayanan R, Mavinahalli J, Verma C, Beuerman RW (2010) The structural parameters for antimicrobial activity, human epithelial cell cytotoxicity and killing mechanism of synthetic monomer and dimer analogues derived from hBD3 C-terminal region. Amino Acids (this issue) 